\author{
Justyna Miko-Giedyk \\ Uniwersytet Jana Kochanowskiego w Kielcach \\ E-MAIL: jumiko@o2.pl
}

\title{
Wiedza i aktywność nauczycieli na rzecz wyrównywania szans edukacyjnych uczniów szkół wiejskich
}

\section{STRESZCZENIE}

W artykule przedstawiona została problematyka działalności nauczycieli na rzecz wyrównywania szans edukacyjnych uczniów ze środowisk wiejskich. Podstawą rozważań są badania empiryczne przeprowadzone w szkołach wiejskich zlokalizowanych w powiecie kieleckim. Teoretyczną podstawą badań jest pedagogika emancypacyjna, zaś w jej obrębie, emancypacyjna teoria edukacji w ujęciu M. Czerepaniak-Walczak. Wyniki badań ukazały niedostateczną wiedzę nauczycieli pracujących na wsi na temat nierówności edukacyjnych, istniejących w ich środowisku czynników utrudniających edukację dzieci i młodzieży oraz możliwości ich niwelowania. Przyczyną tego stanu rzeczy może być to, że polscy nauczyciele nie są odpowiednio przygotowani na podjęcie wielu nowych problemów i wyzwań.

SŁOWA KLUCzOWE: wyrównywanie szans edukacyjnych, nauczyciel, środowisko wiejskie.

Środowisko wiejskie, mimo iż, jak każde inne, poddane zostało ekspansji edukacji mającej w konsekwencji zatrzeć nierówności społeczne w dostępie do tejż $\mathrm{e}^{1}$, nadal jest miejscem, gdzie dzieci i młodzież mają gorsze szanse edukacyjne niż ich rówieśnicy z miast. Z prowadzonych badań socjologa oświaty wiejskiej, Zbigniewa Kwiecińskiego, wynika, że różnice występujące w dostępności, warunkach, poziomie i jakości wykształcenia na wszystkich poziomach edukacji są znaczne i trwałe oraz mogą rzutować na całe dalsze życie². Rozważania nad uzależnieniem szkoły i edukacji od jakości świata, w którym

Szerzej na temat niespełnionych zamierzeń ekspansji edukacyjnej pisze P. Mikiewicz w: Kapitał społeczny i edukacja, PWN, Warszawa 2014, s. 38-50. O niewypełnionej misji edukacji przeciwdziałającej nierównościom społecznym można również przeczytać w pracach M. J. Szymańskiego, m.in. w: Edukacyjne problemy współczesności, Oficyna Wydawnicza Impuls, Kraków - Warszawa 2014, s. 10-11, 143-155.

2 Z. Kwieciński, Między patosem a dekadencją. Studia i szkice socjopedagogiczne, Wydawnictwo Naukowe Dolnośląskiej Szkoły Wyższej Edukacji, Wrocław 2007, s. 39. 
przyszło im działać ${ }^{3}$ oraz badania nad warunkami socjalizacyjno-edukacyjnymi w środowisku wiejskim wskazują, że zróżnicowanie edukacji wiejskiej, wynikające z uwarunkowań makrospołecznych, zaciera się, natomiast o losach dziecka wiejskiego w największym stopniu decydują środowisko lokalne, rodzina i szkoła ${ }^{4}$.

Nadzieje na wyrównywanie szans edukacyjnych daje uczniom wiejskim pracujący w ich środowisku nauczyciel. Celem niniejszego artykułu jest ukazanie przeciętnej aktywności nauczycieli wiejskich na rzecz wyrównywania szans edukacyjnych uczniów, gdzie znaczną rolę odgrywają czynniki intuicyjne, przy niskim udziale świadomych (wyuczonych) kompetencji, oraz zwrócenie uwagi na przyczyny tego stanu rzeczy, tkwiące w niedostatecznym przygotowaniu nauczycieli.

W pierwszej części tekstu przedstawię perspektywę teoretyczną i procedury badań. W dalszej kolejności zaprezentuję uogólnione wyniki badań empirycznych oraz płynące $\mathrm{z}$ nich wnioski. W artykule wykorzystuję badania, które były podstawą mojej dysertacji doktorskiej pt. „Udział nauczycieli w wyrównywaniu szans edukacyjnych młodzieży szkolnej ze środowisk wiejskich"s. Celem poznawczym podjętych badań było zdobycie wiedzy na temat roli nauczycieli w wyrównywaniu szans edukacyjnych młodzieży szkolnej ze środowisk wiejskich, a w szczególności ich wiedzy, motywacji oraz rzeczywistych działań w tym zakresie. Celem praktycznym badań było wypracowanie dyrektyw pedagogicznych, kierowanych pod adresem nauczycieli pragnących efektywniej współpracować z młodzieżą w szkołach zlokalizowanych na wsi oraz próba zbudowania projektu wsparcia dla tych nauczycieli. Ważnym celem praktycznym było wyciągnięcie wniosków na temat lepszego przygotowania nauczycieli w procesie ich kształcenia oraz doskonalenia zawodowego do pracy w wiejskiej placówce.

\section{Perspektywa teoretyczna}

Podstawą teoretyczną badań jest pedagogika emancypacyjna, zaś w jej obrębie emancypacyjna teoria edukacji w ujęciu Marii Czerepaniak-Walczak ${ }^{6}$.

Emancypacja jest świadomym i trwającym w czasie rozpoznawaniem własnych ograniczeń i źródeł opresji, podejmowaniem działań skierowanych

P. Mikiewicz, Kapitał społeczny i edukacja, PWN, Warszawa 2014, s. 58-59.

4 J. Papież, Przemiany warunków socjalizacyjno-edukacyjnych na wsi. Badania panelowe, Oficyna Wydawnicza Impuls, Kraków 2006.

Praca doktorska została napisana pod kierunkiem prof. zw. dr hab. Wandy Dróżki.

$6 \quad$ M. Czerepaniak-Walczak, Pedagogika emancypacyjna. Rozwój świadomości krytycznej człowieka, GWP, Gdańsk 2006, s. 54. 
na ich odrzucenie, świadomym osiąganiem nowych pól wolności i nowych praw oraz odpowiedzialnym i konsekwentnym korzystaniem z nich. Jest to proces uczenia się świadomego wykraczania poza społeczne przyzwolenie z zachowaniem poszanowania praw innych ludzi do doświadczania wolności i sprawiedliwościł. Edukacja jest podstawą emancypacji, ważną drogą przechodzenia od „fałszywej” do „prawdziwej”, to znaczy krytycznej świadomości. Emancypację poprzez szkolną edukację można interpretować dwuwymiarowo: jako świadome uwalnianie się od opresji i ograniczeń, których źródłem jest szkoła i istniejące w niej sytuacje i stosunki interpersonalne mówimy wówczas o emancypacji w szkole; oraz jako źródło awansu społecznego, politycznego i ekonomicznego - poprzez wykształcenie, bowiem młodzi ludzie mogą przekraczać te ograniczenia, które są uwarunkowane ich pochodzeniem - mówimy wówczas o emancypacji poprzez szkołę?.

Ważna jest rola nauczyciela jako organizatora procesów kształcenia i wychowania. Kompetencje nauczyciela wskazywane przez tradycyjną pedagogikę okazują się być szkodliwe z punktu widzenia warunków nabywania i doskonalenia dyspozycji młodzieży do świadomego uwalniania się od ograniczeń oraz projektowania twórczych, innowacyjnych rozwiązań. Z punktu widzenia pedagogiki emancypacyjnej nauczyciel to osoba zdolna do uwalniania się od przesądów, mitów, stereotypów i dzięki temu wpływająca na przekształcenie siebie i innych poprzez akt uczenia $\mathrm{w}$ dwupodmiotowej interakcji. Miejsce oświeconego decydenta powinien zająć organizator zdarzeń i procesów, których uczestnicy mogą rozwijać kompetencje do pokonywania trudności, niesprawiedliwości, nierówności i opresji. Zadaniem nauczyciela - krytycznego partnera - jest towarzyszenie rozwojowi ucznia i równoczesne zmienianie siebie. Wolność człowieka może zapewnić tylko człowiek wolny. Kierowanie procesem nabywania i doskonalenia emancypacyjnych kompetencji ucznia uzależnione jest od stanu tych dyspozycji nauczyciela ${ }^{10}$.

Celem nauczyciela jako organizatora emancypacji poprzez edukację jest tworzenie takich sytuacji edukacyjnych, które są źródłem podmiotowych doświadczeń $\mathrm{w}$ radzeniu sobie $\mathrm{z}$ ograniczeniami i nowymi zadaniami ${ }^{11}$. Powinien on tak kierować edukacją, aby działać w celu „wyzwolenia” uczniów z za-

Eadem, Daleko od... szansy (decyzje edukacyjne młodzieży wiejskiej), Wydawnictwo „PoNaD”, Szczecin 1999, s. 16.

8 Eadem, Pedagogika emancypacyjna..., s. 65.

9 Eadem, Między dostosowaniem a zmianą. Elementy emancypacyjnej teorii edukacji, Wydawnictwo Naukowe Uniwersytetu Szczecińskiego, Szczecin 1994, s. 236.

10 Ibidem, s. 236-237.

1 M. Czerepaniak-Walczak, Pedagogika emancypacyjna..., s. 158. 
stanych norm i ograniczeń. Dzieci i młodzież wiejska, zubożone kulturowo i edukacyjnie z uwagi na swe miejsce zamieszkania, mają szanse „wyzwolić się” z tego „ubóstwa” poprzez odpowiednie działanie nauczyciela.

\section{Procedury badań}

Główny problem badawczy przedstawianych dociekań empirycznych wyraża się w następującym pytaniu: Jaki jest udział nauczycieli w wyrównywaniu szans edukacyjnych młodzieży szkolnej ze środowisk wiejskich? Wyrównywanie przez nauczyciela szans edukacyjnych uczniów ze środowisk wiejskich rozumiane jest jako pomoc uczniom w przezwyciężaniu barier edukacyjnych (w tym również ukazywaniu możliwości i szans rozwoju poprzez wykorzystywanie walorów środowiska wiejskiego), co ma bezpośredni związek $\mathrm{z}$ wiedzą nauczyciela, jego motywacją oraz rozmiarem i rodzajami jego działalności.

Zmienną zależną $\mathrm{w}$ badaniach był udział nauczycieli w wyrównywaniu szans edukacyjnych uczniów, czyli wiedza nauczycieli z zakresu wyrównywania szans, motywacja emancypacyjna, a także konkretne działania kompensacyjne nauczycieli, związane z pomaganiem uczniom w niwelowaniu barier edukacyjnych oraz umożliwieniem im rozwoju poprzez czerpanie z pozytywnych cech środowiska, w którym żyją. Wiedza nauczycieli z zakresu wyrównywania szans dotyczyła znajomości nierówności edukacyjnych w środowisku wiejskim, barier edukacyjnych, walorów środowiska lokalnego oraz umiejętności przeciwdziałania tym nierównościom i barierom. Motywacja emancypacyjna nauczycieli została określona na podstawie ustosunkowania się do stwierdzeń dotyczących świadomości potrzeby wyrównywania szans edukacyjnych uczniów, istniejących w środowisku szkolnym zasobów, pozwalających pomóc pokonać bariery edukacyjne (wyposażenie szkoły, przychylność dyrekcji, czas dla uczniów), wyznawanych wartości, motywów wyboru zawodu, postrzegania roli nauczyciela. Uwzględniając bariery edukacyjne sklasyfikowane przez Mikołaja Kozakiewicza ${ }^{12}$, wyróżniłam sześć rodzajów działań kompensacyjnych nauczycieli, będących odpowiedzią na te bariery: ekonomiczną (wszelka pomoc w pozyskiwaniu stypendiów, różnych dofinansowań, bezpłatnego dożywiania, pozyskiwanie klasowych pieniędzy), przestrzenną i regionalną (opieka nad dowożonymi dziećmi, współpraca z rodzicami, integracja środowiska lokalnego, organizacja wszelkich zajęć pozalekcyjnych bezpośrednio po lekcjach, aby dzieci mieszkające w znacznej odległości od szkoły też mogły w nich uczestniczyć), psychologiczną (kształ-

12 M. Kozakiewicz, Bariery awansu poprzez wykształcenie, IW CRZZ, Warszawa 1974. 
towanie pożądanych umiejętności społecznych, wzmacnianie aspiracji edukacyjnych, poczucia własnej wartości, stosowanie oceniania kształtującego), edukacyjno-zawodową (doradzanie w wyborze dalszej edukacji, w wyborze zawodu, umożliwianie konsultacji ze specjalistami zajmującymi się poradnictwem edukacyjno-zawodowym, społeczno-kulturową (organizowanie kół zainteresowań, innych zajęć pozalekcyjnych, uroczystości szkolnych i środowiskowych, współpraca środowiskowa, z instytucjami lokalnymi, edukacja regionalna z wykorzystaniem walorów środowiska lokalnego), szkolno-oświatową (organizowanie zajęć wyrównawczych, stosowanie podczas zajęć dydaktycznych metody projektu, przygotowywanie autorskich programów, dokształcanie nauczycieli, przygotowanie do pracy w wiejskiej placówce).

Dane empiryczne prezentowane w tekście zebrane zostały za pomocą metody sondażu diagnostycznego. Badania zostały przeprowadzone w szkołach podstawowych i gimnazjach na obszarach wiejskich powiatu kieleckiego. Pierwszym kryterium doboru próby badawczej był typ administracyjny środowiska (miejsko-wiejskie i wiejskie), drugim kryterium - wskaźnik ME (możliwości edukacyjne) środowiska i zróżnicowanie pod względem wielkości, typu funkcjonalnego lub graniczenia z miastem, trzecim kryterium najbardziej skrajny wskaźnik WE szkoły (wynik egzaminu) i wielkość szkoły. W doborze próby chodziło o wyszukanie środowisk najbardziej różniących się od siebie, zarówno powierzchnią, położeniem, jak i możliwościami edukacyjnymi. Wskaźnik ME został określony na podstawie wydatków na oświatę w gminie, liczby szkół w gminie w stosunku do liczby sołectw (ma to swoje powiązanie z powierzchnią) oraz wyników sprawdzianów i egzaminów szkół podstawowych i gimnazjów mieszczących się na terenie gminy.

Do badań zostało zakwalifikowanych siedem gmin z powiatu kieleckiego ziemskiego i osiemnaście szkół z tych gmin. Ostatecznie badania przeprowadzono w 17 szkołach, gdyż dyrektor jednej ze szkół nie zgodził się na współpracę, zaś niemożliwe było wylosowanie placówki podobnego typu. Do wzięcia udziału w badaniach zostali zaproszeni wszyscy nauczyciele $\mathrm{z}$ terenu badań. Pozytywnie odpowiedziało (wypełniając ankiety) 205 nauczycieli, którzy stanową 51\% wszystkich nauczycieli pracujących w wylosowanych do badań szkołach.

\section{Wyniki badań}

Analiza zebranych w badaniach danych empirycznych wykazała, że nauczyciele nie prezentują wysokiego poziomu znajomości przeszkód edukacyjnych występujących w środowisku wiejskim. Graficzny obraz średniego 


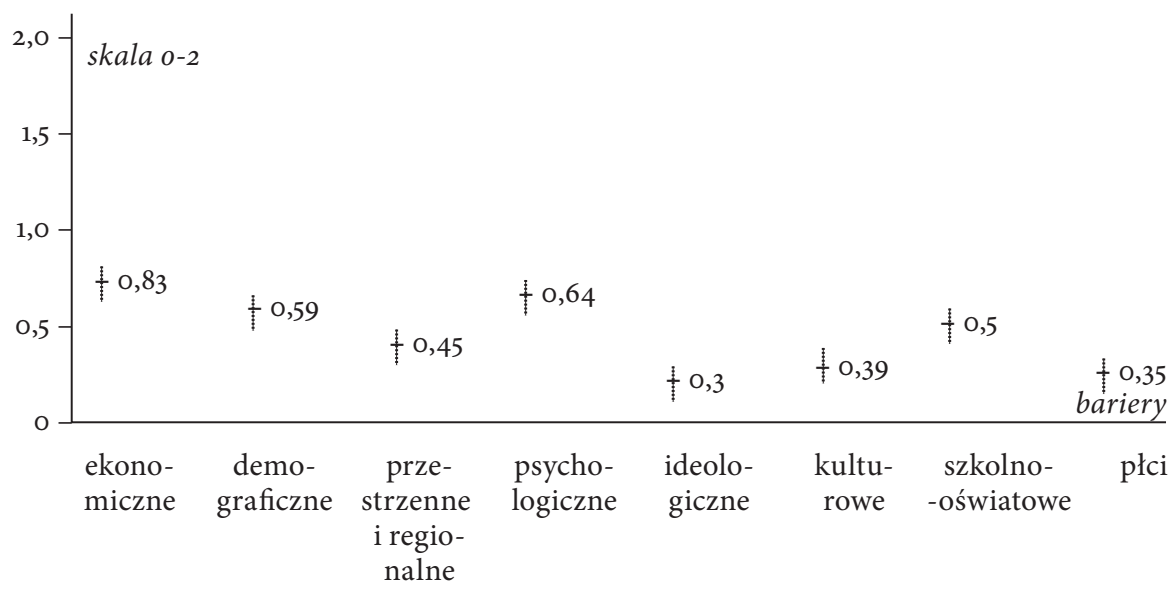

Wykres 1. Przeciętne natężenie znajomości poszczególnych rodzajów barier edukacyjnych

Źródło: badania własne.

natężenia wiedzy o barierach edukacyjnych został przedstawiony na wykresie 1 .

Najlepiej poznanymi przeszkodami edukacyjnymi są bariery ekonomiczne i psychologiczne, a najmniej - bariera ideologiczna i płci.

Niezadowalająca jest wiedza nauczycieli na temat sposobów łagodzenia przeszkód edukacyjnych występujących w środowisku. Najlepiej wśród badanych wypadło niwelowanie barier ekonomicznych i psychologicznych, najsłabiej zaś - barier ideologicznych i szkolno-oświatowych (wykres 2), co można tłumaczyć korzystaniem przez nauczycieli z wiedzy potocznej oraz stereotypowym myśleniem o edukacji ${ }^{13}$.

Badani nauczyciele wykazali przeciętną znajomość walorów środowiska lokalnego, w którym pracują, a często także zamieszkują. Największy zasób wiedzy mają o walorach turystycznych i historycznych środowiska, natomiast najmniejszy - o walorach przyrodniczych (wykres 3).

Nauczyciele uczący w szkołach średniej wielkości mają wyższy poziom badanej wiedzy niż ich koledzy pracujący w szkołach małych i dużych (wykres 4).

${ }_{13}$ T. Hejnicka-Bezwińska, Gotowość nauczycieli do funkcjonowania w standardach podmiotowych, [w:] „Gorace” problemy edukacji w Polsce, T. Lewowicki (red.), KNP PAN, WSP ZNP, Warszawa 2007, s. 283; D. Waloszek, Epistemologia niepewności w działaniu nauczyciela, [w:] Trwałość i zmiana. Pytanie o edukacje, J. Góral-Półrola, M. Wojciechowska, B. Walasek-Jarosz (red.), Oficyna Wydawnicza Staropolskiej Szkoły Wyższej w Kiecach, Kielce 2014, s. 188-189. 
124 J. MIKO-GIEDYK .

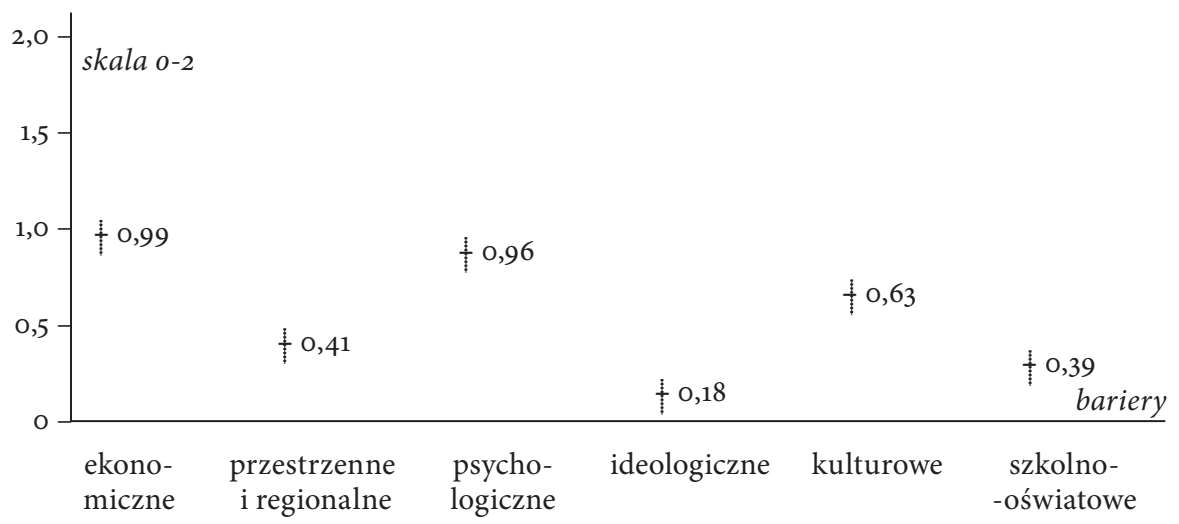

Wykres 2. Przeciętne natężenie znajomości sposobów niwelowania poszczególnych rodzajów barier edukacyjnych

Źródło: badania własne.

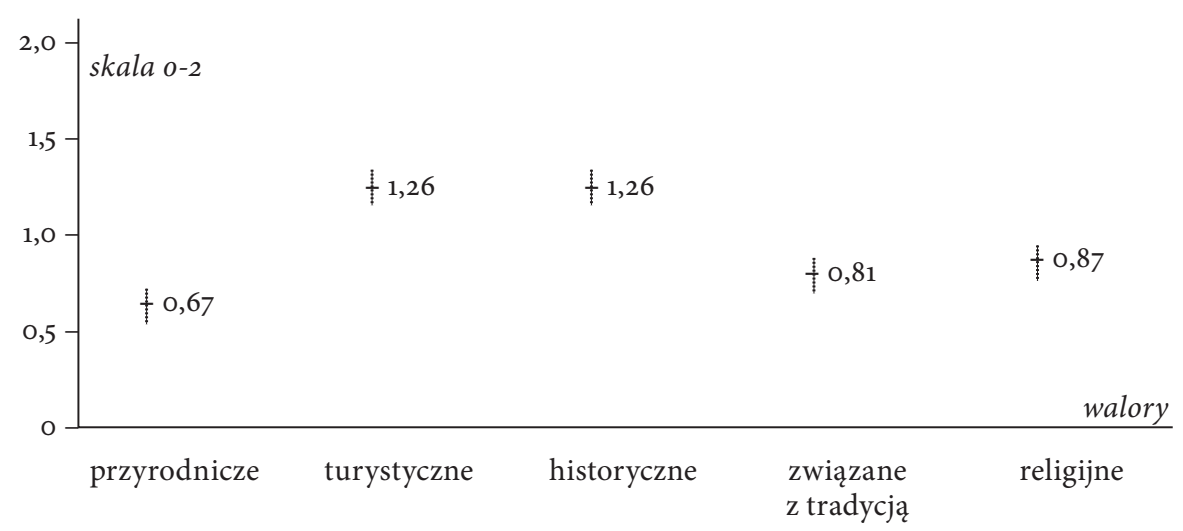

Wykres 3. Przeciętne natężenie znajomości poszczególnych walorów środowiska lokalnego

Źródło: badania własne.

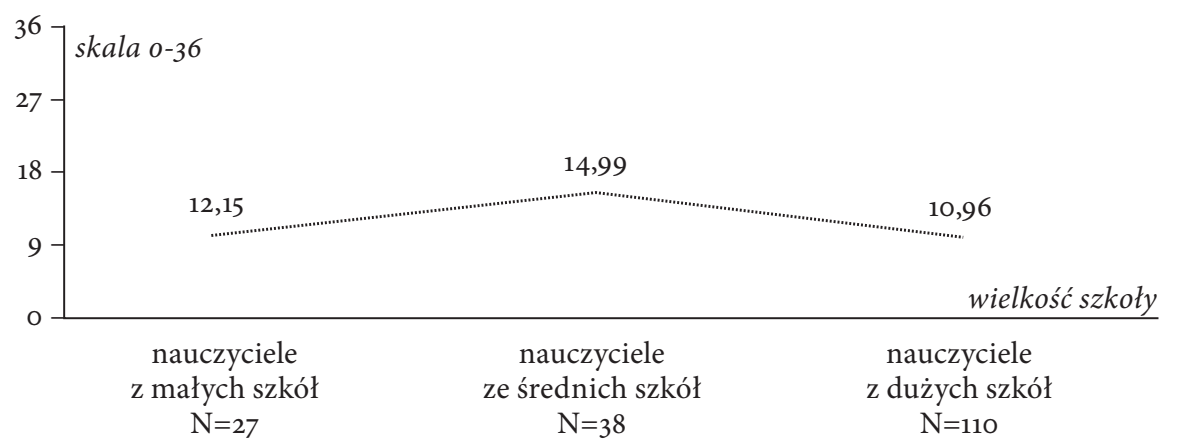

Wykres 4. Przeciętne natężenie wiedzy nauczycieli względem wielkości szkół

Źródło: badania własne. 


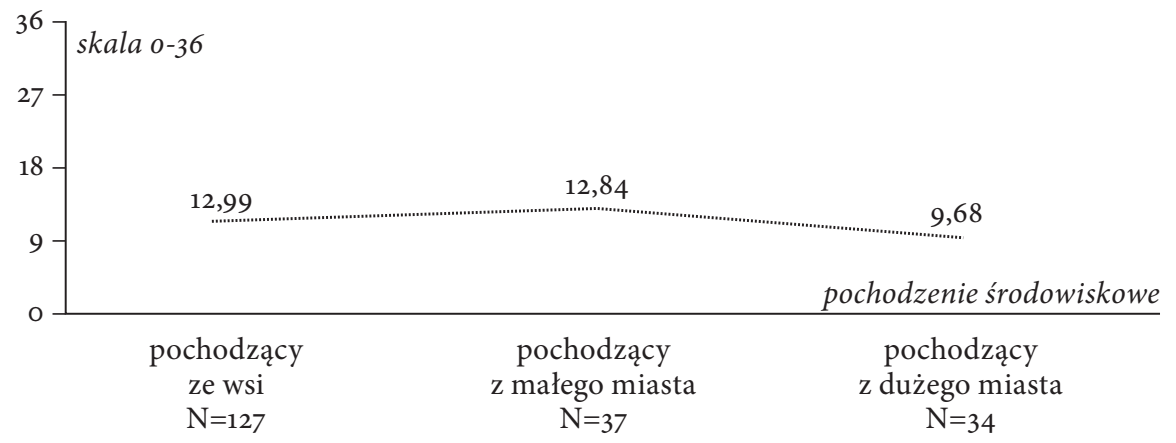

Wykres 5. Średnie natężenie wiedzy badanych względem pochodzenia środowiskowego

Źródło: badania własne.

Średnia wielkość szkoły wydaje się być najkorzystniejsza z punktu widzenia wiedzy nauczycieli o środowisku lokalnym w kontekście wyrównywania szans edukacyjnych. Dużo bogatszą wiedzą wykazali się nauczyciele pochodzący ze środowisk wiejskich niż ci, którzy wywodzą się z miast (wykres 5), co oznacza, że nauczyciele urodzeni i wychowani na wsi znają lepiej to środowisko i jego problemy. Potwierdzenie tej tezy znajdujemy w słowach J. Delorsa, który w swoim Raporcie stwierdził: „Kiedy nauczyciele stanowią sami część społeczności, w której uczą, bardziej są wyczuleni na potrzeby tej społeczności i są w stanie lepiej przyczyniać się do realizacji jej celów”"14.

Badani nauczyciele $\mathrm{w}$ większości posiadają wysoki poziom motywacji emancypacyjnej we wszystkich jej typach przyjętych arbitralnie i potwierdzonych analizą czynnikową: „poczucie misji nauczycielskiej”, „poczucie zasadności wyrównywania szans edukacyjnych”, „powołanie nauczycielskie”, „poczucie sprzyjania idei wyrównywania szans edukacyjnych i wartości prorodzinne". Różnice w poziomach typów motywacji w poszczególnych grupach (ze względu na płeć, wiek, miejsce zamieszkania, pochodzenie środowiskowe, stopień awansu, wielkość szkoły) były stosunkowo niewielkie i tylko w niektórych przypadkach istotne statystycznie ${ }^{15}$. Motywacja związana z poczuciem misji nauczycielskiej jest wyższa u nauczycieli uczących w małych szkołach (wykres 6) oraz nauczycieli wywodzących się ze środowisk wiejskich (wykres 7). Mniejsze środowiska, zarówno pochodzenia, jak i przebywania (miejsce pracy), wpływają na silniejsze odczuwanie zawodu nauczy-

14 J. Delors, Edukacja. Jest w niej ukryty skarb, Raport dla UNESCO Międzynarodowej Komisji do spraw Edukacji dla XXI wieku, UNESCO, Warszawa 1998, s. 158.

15 Różnice były weryfikowane za pomocą jednoczynnikowej analizy wariancji i testów porównań wielokrotnych - Tukeya i Duncana. 


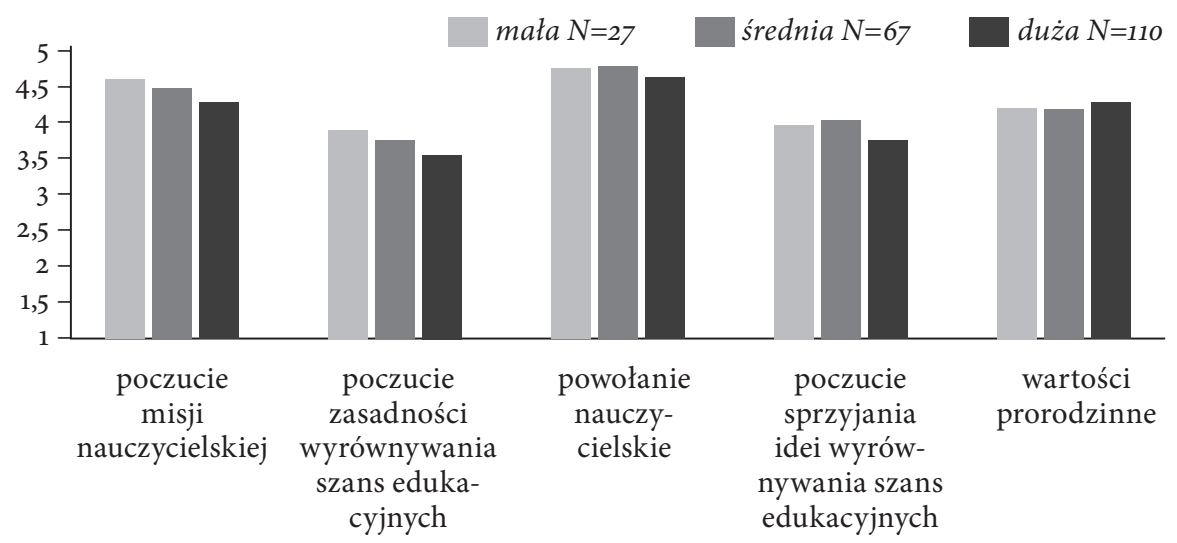

Wykres 6. Zróżnicowanie typów motywacji w grupach wielkości szkoły Źródło: badania własne.

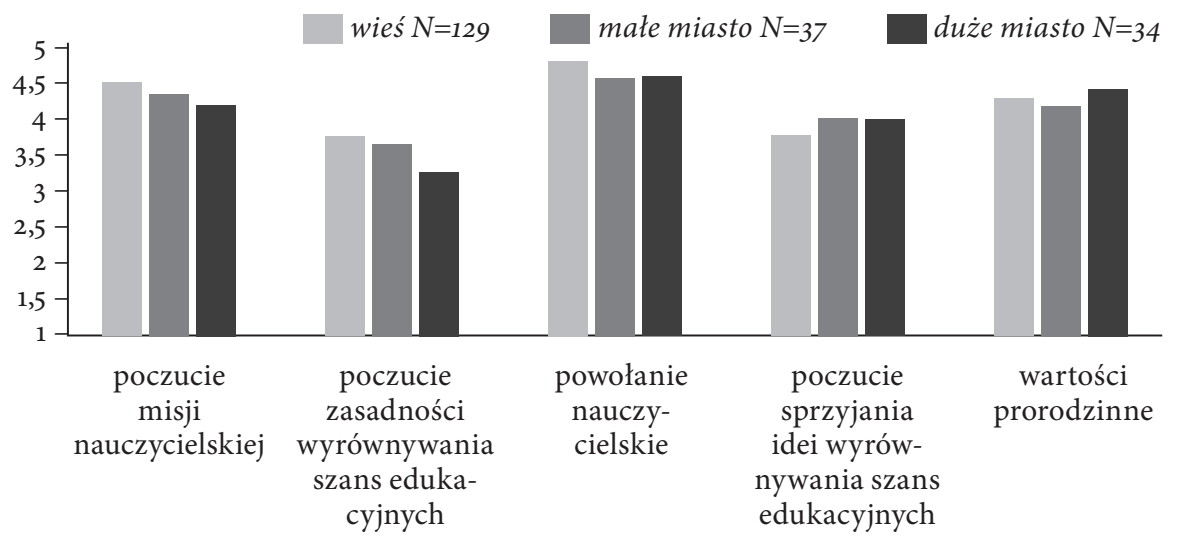

Wykres 7. Zróżnicowanie typów motywacji w grupach pochodzenia środowiskowego

Źródło: badania własne.

cielskiego jako misji do spełnienia, jego znaczenia dla rozwoju społeczeństwa, a także poczucia społecznego zobowiązania.

„Poczucie zasadności wyrównywania szans edukacyjnych” jest wyraźnie wyższe w grupie nauczycieli starszych (wykres 8). Można to wyjaśnić tym, że wraz z wiekiem rośnie doświadczenie życiowe, co przekłada się na świadomość istnienia wielu problemów. Starsi nauczyciele mają głębsze przekonanie o tym, że edukacja wpływa na losy życiowe uczniów oraz w większej mierze zdają sobie sprawę z tego, że uczniowie mieszkający w środowisku wiejskim mają często gorsze szanse edukacyjne. Wyższy poziom motywacji tego typu został zauważony wśród nauczycieli pochodzących ze wsi (wykres 7) i mieszkających w tym środowisku (wykres 9). 


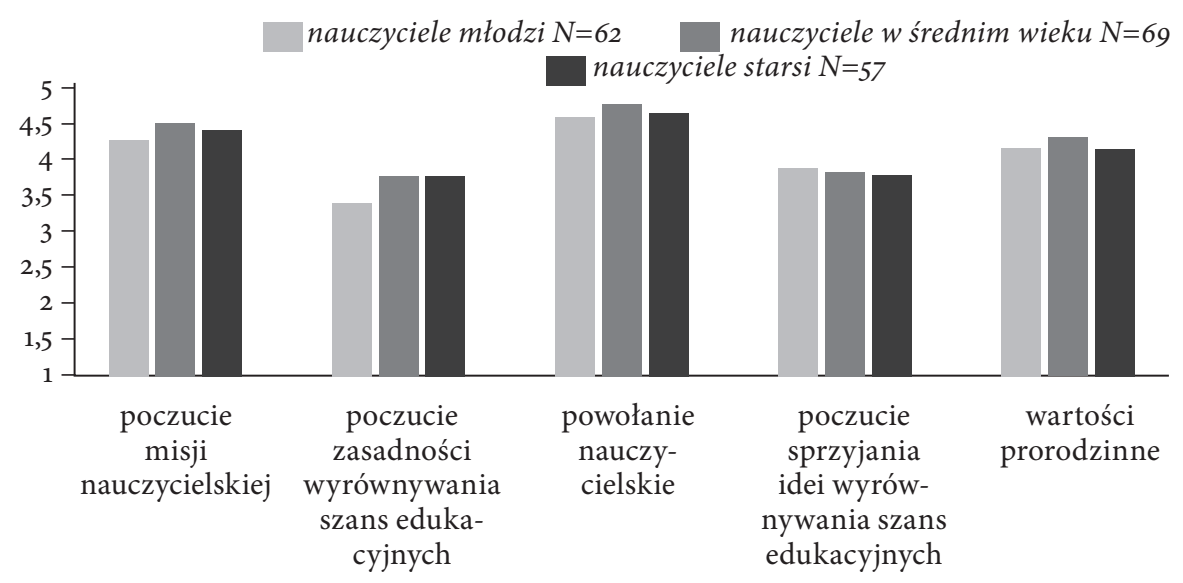

Wykres 8. Zróżnicowanie typów motywacji w grupach wieku

Źródło: badania własne.

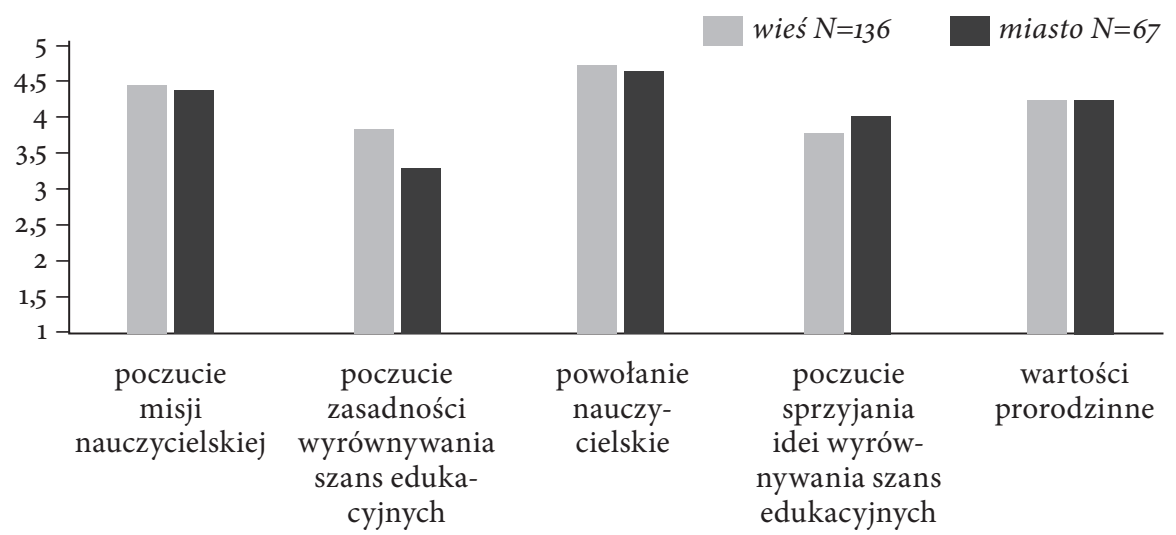

Wykres 9. Zróżnicowanie typów motywacji w grupach miejsca zamieszkania

Źródło: badania własne.

„Powołanie nauczycielskie” jako rodzaj motywacji do działalności edukacyjnej jest również silniejsze u nauczycieli mieszkających na wsi. Zostało to już zauważone we wcześniejszych badaniach nad młodym pokoleniem nauczycieli, które prowadziła Wanda Dróżka. Motyw powołania miał u tych nauczycieli wpływ na wybór zawodu nauczycielskiego jako tego, który ma wysokie znaczenie społeczne, dzięki któremu zdobywa się wyższą pozycję społeczną oraz poważanie w środowisku, które to wartości są nadal cenione wśród społeczności wiejskiej ${ }^{16}$.

16 W. Dróżka, Młode pokolenie nauczycieli, Studium autobiografii młodych nauczycieli polskich lat dziewięćdziesiątych, Wydawnictwo Wyższej Szkoły Pedagogicznej im. Jana Kochanowskiego w Kielcach, Kielce 1997, s. 244. 


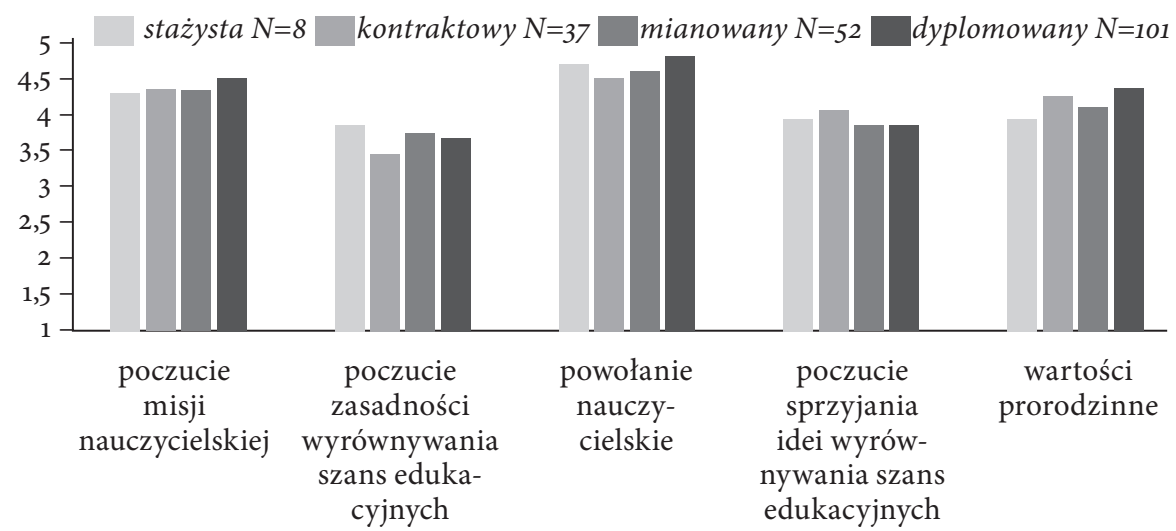

Wykres 10. Zróżnicowanie typów motywacji w grupach stopni awansu zawodowego

Źródło: badania własne.

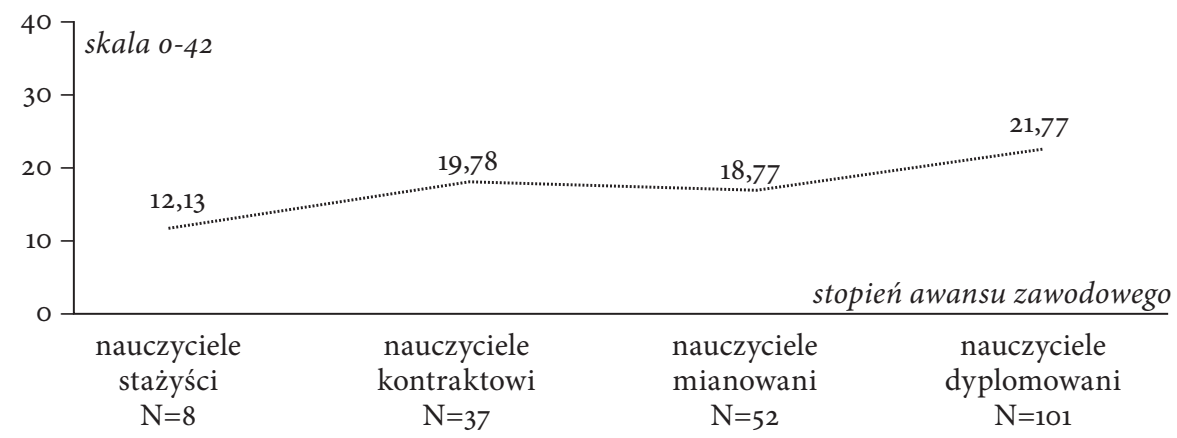

Wykres 11. Przeciętne natężenie aktywności kompensacyjnej badanych nauczycieli w grupach stopni awansu zawodowego (w punktach)

Źródło: badania własne.

Typ kolejny: poczucie sprzyjania idei wyrównywania szans edukacyjnych, jest charakterystyczny dla respondentów mieszkających w mieście i dojeżdżających do pracy na wieś (wykres 9). Typ motywacji - wartości prorodzinne charakteryzuje nauczycieli dyplomowanych (wykres 10).

Aktywność kompensacyjna nauczycieli jest wświetle przeprowadzonych badań przeciętna. Czynnikami różnicującymi tę aktywnośćc ${ }^{17}$ są stopień awansu zawodowego, staż pracy i wielkość szkoły (wykresy 11, 12, 13).

Mniejsza aktywność nauczycieli pochodzących ze wsi i małych miast, szczególnie ta o charakterze psychologicznym (wykres 14), edukacyjno-zawodo-

${ }_{17}$ Różnice były weryfikowane za pomocą jednoczynnikowej analizy wariancji i testów porównań wielokrotnych - Tukeya i Duncana. 


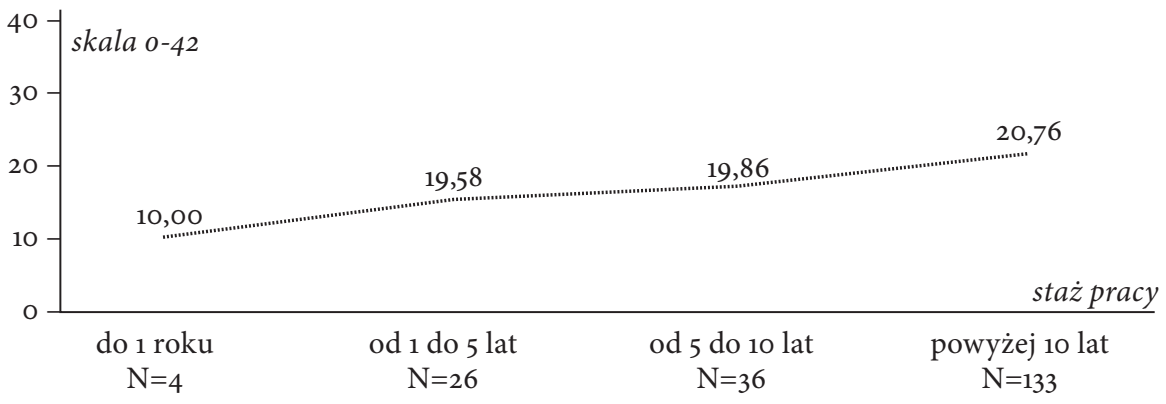

Wykres 12. Przeciętne natężenie aktywności kompensacyjnej badanych nauczycieli w grupach stażu pracy (w punktach)

Źródło: badania własne.

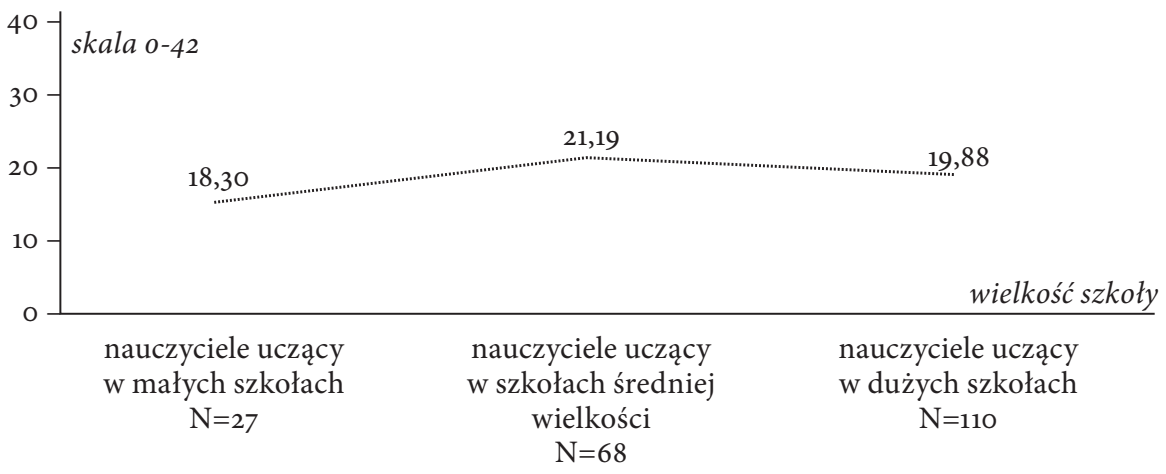

Wykres 13. Przeciętne natężenie działalności kompensacyjnej nauczycieli w grupach wielkości szkoły (w punktach)

Źródło: badania własne.

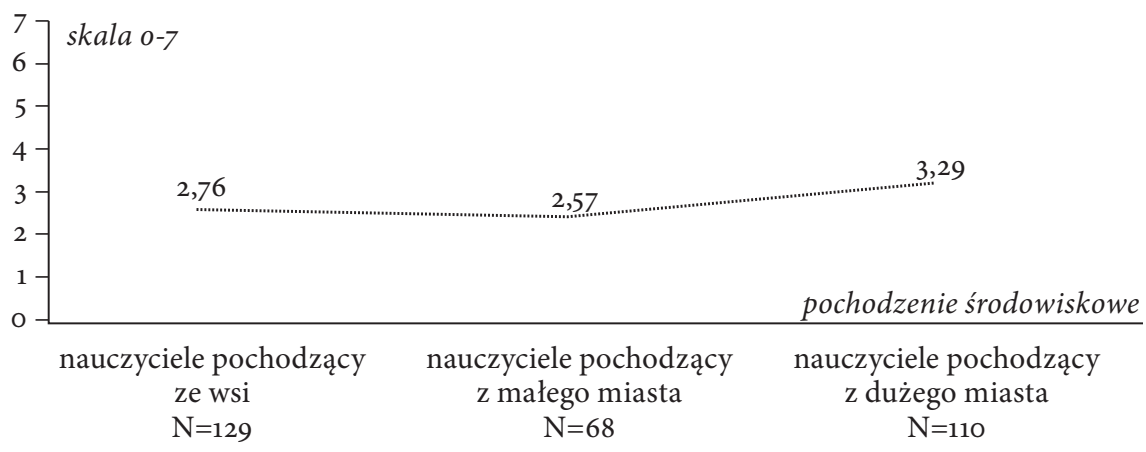

Wykres 14. Przeciętne natężenie działalności psychologicznej nauczycieli w grupach pochodzenia środowiskowego (w punktach)

Źródło: badania własne. 


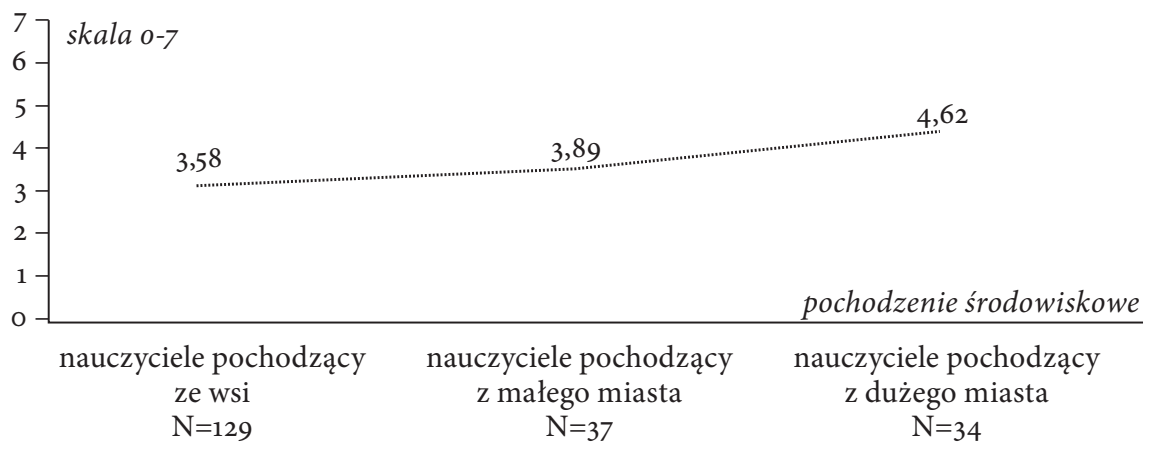

Wykres 15. Przeciętne natężenie działalności edukacyjno-zawodowej nauczycieli w grupach pochodzenia środowiskowego (w punktach)

Źródło: badania własne.

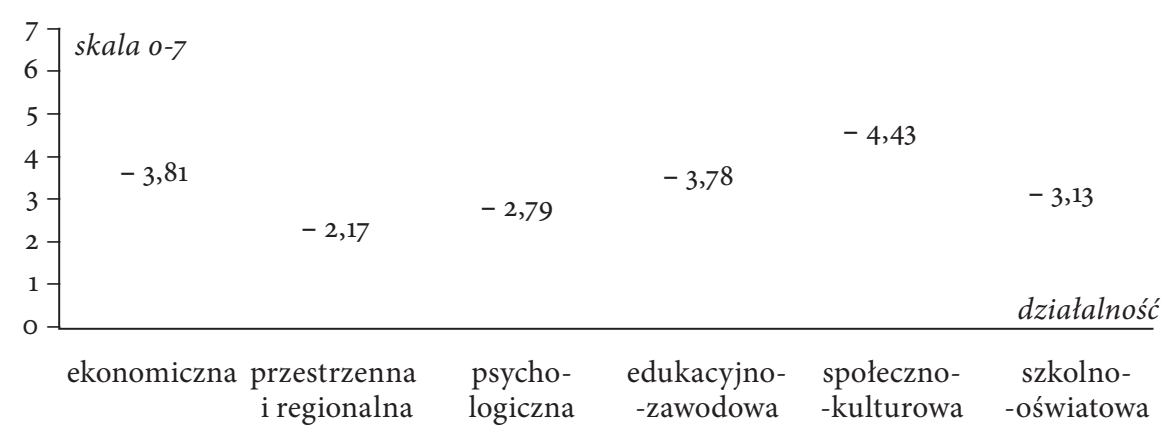

Wykres 16. Przeciętne natężenie różnych rodzajów działalności kompensacyjnej badanych nauczycieli

Źródło: badania własne.

wym (wykres 15), szkolno-oświatowym, może wynikać z mniejszej skłonności do podejmowania działań w ogóle ${ }^{18}$. Wieś co prawda wychowuje do aktywności, dzieciom wcześniej niż w mieście powierza się tu szereg obowiązków, młodzież wiejska mniej chętnie liczy na pomoc innych w sytuacjach trudnych, ale jest to aktywność raczej zrytualizowana, dotycząca czynności bardziej „technologicznych" ${ }^{\prime \prime}$. Nie przekłada się ona na podejmowanie choćby dodatkowych zadań przez nauczycieli wywodzących się z tych środowisk. Dlatego dużo wyższą aktywnością wykazali się nauczyciele pochodzący z dużych miast.

Badani nauczyciele charakteryzują się zróżnicowanym poziomem poszczególnych rodzajów działalności kompensacyjnej (wykres 16). Z przeanalizowa-

${ }_{18}$ M. Kwiecińska-Zdrenka, Aktywni czy bezradni wobec własnej przyszłości?, Młodzież wiejska na tle ogółu młodzieży, Wydawnictwo Uniwersytetu Mikołaja Kopernika, Toruń 2004, s. 119.

19 Ibidem. 
nych rodzajów aktywności wynika, iż badani najbardziej angażują się w działalność społeczno-kulturową, ekonomiczną i edukacyjno-zawodową. Najmniej natomiast w przestrzenną i regionalną.

\section{Konkluzje}

Przyjęcie emancypacyjnej teorii edukacji jako perspektywy wyjaśniania i interpretacji udziału nauczycieli w procesie wyrównywania szans edukacyjnych w środowisku wiejskim pozwala na dostrzeżenie niektórych czynników generujących podmiotową aktywność ukierunkowaną na świadomą zmianę. Emancypacja jest bowiem procesem ustawicznego uczenia się reakcji na ograniczenia i opresję, stosownie do lokalnych warunków ${ }^{20}$. Aktywność nauczycieli we wszystkich sześciu rodzajach działalności nastawionej na pokonywanie barier edukacyjnych tkwiących w środowisku sprzyja uświadamianiu społecznościom wiejskim, w tym dzieciom i młodzieży szkolnej, ich położenia oraz ukazywaniu wizji, sensu i możliwości wspólnej pracy nad zmianą.

Problemem, który naświetliły wyniki badań, jest wciąż niedostateczna wiedza nauczycieli pracujących na wsi na temat nierówności edukacyjnych, istniejących wich środowisku czynników utrudniających edukację dzieci i młodzieży oraz możliwości ich niwelowania. Jednakże analiza rozmiarów aktywności nauczycieli, która okazała się być na wyższym poziomie niż ich wiedza, pozwala sądzić, że intuicyjnie podejmują oni starania przeciwdziałające ograniczeniom. Może to prowadzić do uzmysłowienia sobie przez uczniów wiejskich swojego położenia, odczucia potrzeby zmiany i dążenia do niej.

Przyczyną niedostatecznej wiedzy i umiejętności nauczycieli, ich kompetencji w zakresie wyrównywania szans edukacyjnych, może być to, że polscy nauczyciele nie są odpowiednio przygotowani na podjęcie wielu nowych problemów i wyzwań, jakie przed nimi stają w społeczeństwie doświadczającym radykalnych przemian we wszystkich dziedzinach. Tymczasem kształcenie nauczycieli powinno wprowadzać ich w wiedzę, dawać podstawy umiejętności, a także kształtować postawy i uwrażliwiać na specyficzne sytuacje występujące w szkolnictwie w naszym kraju, w tym na swoiste warunki środowiskowe, z jakimi mamy do czynienia w szkołach na wsi. Współczesny nauczyciel musi zdawać sobie sprawę z tego, że na coraz bardziej zróżnicowanych ekonomicznie i społecznie obszarach wiejskich mogą występować odmienne potrzeby, oczekiwania i warunki do pracy pedagogicznej. Ważnym zadaniem edukacji nauczycieli jest kształtowanie ich świadomości roli

2o $\quad$ M. Czerepaniak-Walczak, Daleko od... szansy..., s. 97. 
społecznej, która dziś częściej jest interpretowana w kategoriach emancypacji społecznej i kulturowej, a także w kategoriach znaczenia i zadań nauczycieli związanych z prowadzoną przez Unię Europejską polityką inkluzji społecznej poprzez edukację oraz politykę spójności i zrównoważonego rozwoju ${ }^{21}$.

Każdy wychowawca powinien wykazywać się krytyczną refleksją przy podejmowaniu swych różnorodnych zadań. Wymaga to jednak uwolnienia się od naiwności oraz przesadnego deterministycznego tkwienia w stereotypach i mitach wytworzonych na przestrzeni historii oraz upowszechnianych i utrwalanych $\mathrm{w}$ mediach ${ }^{22}$. Emancypacyjna teoria edukacji jest szczególnym typem uczestniczenia $\mathrm{w}$ procesie poznania i zmiany społecznej. Polega na jednoczesnym zaangażowaniu się w odkrywanie mechanizmów rządzących uwalnianiem się od doświadczanej opresji, konstruowanie projektów zmiany oraz ich praktyczne wdrażanie ${ }^{23}$.

Im większe przeszkody ma do pokonania uczeń: ubóstwo, trudne środowisko społeczne, ułomności fizyczne, tym więcej wymaga się od nauczyciela. Aby jego działania były skuteczne, powinien dysponować różnorodnymi kompetencjami pedagogicznymi, społecznymi i kulturowymi. Kompetencje te, a zwłaszcza dotyczące nierówności społecznych w edukacji oraz sposobów ich kompensowania, a także pracy z uczniem słabym i poddanym różnym deprywacjom społecznym, kulturowym i środowiskowym nauczyciel powinien zdobywać w toku kształcenia oraz dokształcania, zaś odpowiednie treści powinny się znaleźć $\mathrm{w}$ standardach kształcenia na studiach pedagogicznych, a także w programach kursów i szkoleń dokształcających ${ }^{24}$.

\section{BIBLIOGRAFIA}

Czerepaniak-Walczak M., Daleko od... szansy (decyzje edukacyjne młodzieży wiejskiej), Wydawnictwo „PoNaD”, Szczecin 1999.

Czerepaniak-Walczak M., Między dostosowaniem a zmianą. Elementy emancypacyjnej teorii edukacji, Wydawnictwo Naukowe Uniwersytetu Szczecińskiego, Szczecin 1994.

Czerepaniak-Walczak M., Pedagogika emancypacyjna. Rozwój świadomości krytycznej człowieka, GWP, Gdańsk 2006.

Czerepaniak-Walczak M., Stereotypy młodzieży: konieczność i możliwość odczarowania młodości, [w:] Wychowanie. Pojęcia. Procesy. Konteksty, t. 1, M. Dudzikowa, M. Czerepaniak-Walczak (red.), GWP, Gdańsk 2007.

${ }_{21}$ Teacher Education for Inclusion. Changing Paradigms and Innovative Approaches, Ch. Forlin red.), Routledge, Taylor\&Francis Group, Great Britain, 2010.

22 M. Czerepaniak-Walczak, Stereotypy młodzieży: konieczność i możliwość odczarowania młodości, [w:] Wychowanie. Pojęcia. Procesy. Konteksty, t. 1, M. Dudzikowa, M. Czerepaniak-Walczak (red.), GWP, Gdańsk 2007, s. 178.

23 M. Czerepaniak-Walczak, Pedagogika emancypacyjna..., s. 72.

${ }^{24}$ B. Murawska, E. Putkiewicz, R. Dolata, Wsparcie rozwoju zawodowego a potrzeby nauczycieli w tym zakresie, Instytut Spraw Publicznych, Warszawa 2005, s. 165. 
Delors J., Edukacja. Jest w niej ukryty skarb, Raport dla UNESCO Międzynarodowej Komisji do spraw Edukacji dla XXI wieku, UNESCO, Warszawa 1998.

Dróżka W., Młode pokolenie nauczycieli, Studium autobiografii młodych nauczycieli polskich lat dziewięćdziesiątych, Wydawnictwo Wyższej Szkoły Pedagogicznej im. Jana Kochanowskiego w Kielcach, Kielce 1997.

Hejnicka-Bezwińska T., Gotowość nauczycieli do funkcjonowania w standardach podmiotowych, [w:] „Gorace” problemy edukacji w Polsce, T. Lewowicki (red.), KNP PAN, WSP ZNP, Warszawa 2007.

Kozakiewicz M., Bariery awansu poprzez wykształcenie, IW CRZZ, Warszawa 1974.

Kwiecińska-Zdrenka M., Aktywni czy bezradni wobec własnej przyszłości?, Młodzież wiejska na tle ogółu młodzieży, Wydawnictwo Uniwersytetu Mikołaja Kopernika, Torun 2004.

Kwieciński Z., Między patosem a dekadencją. Studia i szkice socjopedagogiczne, Wydawnictwo Naukowe Dolnośląskiej Szkoły Wyższej Edukacji, Wrocław 2007.

Mikiewicz P., Kapitał społeczny i edukacja, PWN, Warszawa 2014.

Murawska B., Putkiewicz E., Dolata R., Wsparcie rozwoju zawodowego a potrzeby nauczycieli w tym zakresie, Instytut Spraw Publicznych, Warszawa 2005.

Papież J., Przemiany warunków socjalizacyjno-edukacyjnych na wsi. Badania panelowe, Oficyna Wydawnicza Impuls, Kraków 2006.

Teacher Education for Inclusion. Changing Paradigms and Innovative Approaches, Ch. Forlin (ed.), Routledge, Taylor\&Francis Group, Great Britain, 2010.

Szymański M. J., Edukacyjne problemy współczesności, Oficyna Wydawnicza Impuls, Kraków - Warszawa 2014.

Waloszek D., Epistemologia niepewności w działaniu nauczyciela, [w:] Trwałość i zmiana. Pytanie o edukacje, J. Góral-Półrola, M. Wojciechowska, B. Walasek-Jarosz (red.), Oficyna Wydawnicza Staropolskiej Szkoły Wyższej w Kiecach, Kielce 2014.

\section{SUMMARY}

\section{The role of the teacher \\ in creating equal educational opportunities in rural areas}

The article discusses the actions of teachers aimed at equalizing educational opportunities of students from rural areas. The analysis relies on the empirical research conducted in the rural schools located in Kielce County. The article is based on the pedagogy of emancipation, and within this pedagogy, on the emancipation theory of education presented by M. Czerepaniak-Walczak. The results of the research showed insufficient knowledge of the teachers working in the country, regarding educational inequalities, the existence of factors impeding education of children and youth, as well as the possibilities to reduce these disparities. The reason for such a situation might be the fact that Polish teachers are not appropriately prepared to face many new problems and challenges.

KEY WORDS: equalizing educational opportunities, teacher, rural area. 